\title{
THE EFFECT OF MEDICAL EXPERIENCES ON INSTITUTIONAL BETRAYAL, TRUST IN DOCTOR AND PATIENT TRUST TO HEALTH CARE IN INDONESIA
}

\author{
Indrawati Ratna*, Harsoyo Agus \\ University of Esa Unggul, Indonesia \\ *E-mail: ratna.indrawati@esaunggul.ac.id
}

\begin{abstract}
The hospital health service industry needs to have optimal services with quality human resources seeing many similar endeavors. Competing in similar industries requires patient trust. Confidence comes from the idea that the parties involved will provide the best quality. Therefore, in this case, the patient's trust is measured by experience, betrayal of the institution, and faith in doctors. This research thus seeks to examine the impact of medical expertise on betrayal institutional, the doctor's confidence, and patient trust in health care. The technique of sampling is purposeful sampling sample of outpatients at hospitals in the Jakarta area is 305 . This type of research is deductive, with data collection by distributing questionnaires. The analytical method used is the Structural Equation Model (SEM). The study results conclude: First, there is an effect of medical experiences on institutional betrayal. Secondly, there is an impact of institutional betrayal of trust in-hospital treatment. Three, medical experiences have an impact on patients' confidence in healthcare. Four, the impact of doctor trust on the confidence of individuals in healthcare. This study indicates that hospital leaders may provide training, development to enhance medical officers' abilities and know-how, and improve hospital performance systems to offer video satisfaction services and reduce the incidence of institutional betrayal to establish confidence for patients.
\end{abstract}

\section{KEY WORDS}

Medical experience, betrayal institutional, trust in doctor, patient trust, health care, hospital.

Amor, Talbi explain the continuity of hospital life, and Almubrad (2018) requires a hospital culture, efficient, effective, innovative, and reliable management to impact patient/client loyalty. Therefore, it is vital to foster a sense of trust in customers when customers need health services, seeing many similar industries (Amalia, 2013; Hulu and Ruswanti, 2018; Rasiah et al., 2020). However, the study of Kim et al. (2018) said that trust in doctors did not influence patient confidence in Korean hospitals. This is because Koreans have low faith in doctors. It can be said that they have had an unpleasant experience.

According to Xie et al. (2019), a pleasant patient experience comes from the health services received for the quality provided. Therefore, the organization needs to gain the trust of its patients, which is formed based on experience. Brenann et al. (2013); Sieck, Hefner, and McAlearney. (2018); Rasiah et al. (2020) said that patient experience impacts patients' trust in health services. It's just that the implementation of hospital services is sometimes found in conditions that are detrimental to patients psychologically, physically, and financially (Brennan and Monson, 2014). This situation, although unintentional, is seen as involving the hospital system, managers, doctors, and nurses, so it is known as betrayal institutional (B.I.) (Smith and Freyd, 2014). Betrayal institutional occurs when someone feels aggrieved by a trusted party (Smith, 2017). For patients who have high trust and hope, getting health services at the hospital will undoubtedly handle the situation as an unpleasant medical experience (Taian, Klest, and Mutchsler, 2017).

The hospital needs to create a medical experience following what patients expect to prevent things that are not desirable, as the results of research by T Tran et al. (2017) and Klestet al. (2020) that medical experience influences institutional betrayal. If institutional treason takes place, it would affect the loss of trust and loyalty of the patients, including health service providers such as doctors and nurses, so that patients decide not to return to hospital later, Dugan (2005). Shoemaker and Smith (2019), Lewis et al. (2019) said, of 
course (Henrick, Brennan, and Monturo, 2016). If institutional treason takes place, it would affect the loss of trust and loyalty of the patients, including health service providers such as doctors and nurses, so that patients decide not to return to hospital later, Dugan (2005). Shoemaker and Smith (2019), Lewis et al. (2019) said, of course (Henrick, Brennan, and Monturo, 2016). This is following the results of research by Hall et al. (2002), Dugan et al. (2005), Zhao et al. (2015) stated that trust in doctors influences patients' trust in health services.

Health services are essential in everyday human life. It involves uncertainty so that mutual respect, trust, and cooperation in medical services are needed (Fiscella et al., 2004). The health services provided must also be following what is required. Therefore, professional hospitals should provide services and continue to improve quality because patients or prospective patients have many choices to choose the desired hospital (Sarkerand Uddin, 2013). However, Kim et al. (2018) said there are still patients who experience unpleasant experiences due to irresponsible persons so that patients do not make repeat visits. Even though this institutional betrayal situation is not common in hospitals, prevention still needs to be done to minimize harmful things for the hospital's success (Smith and Freyd, 2014).

However, the research results have not supported research conducted by Kim et al. (2018) showing that doctor confidence does not have any influence over patient confidence based on female gender in Korean hospitals in general, compared with male gender. Korean women do not treat conventional hospitals with medical care, but prefer traditional health care. While the research results by Shoemaker and Smith (2019), experience does not affect patients' trust in midwifery medicine because they have had unpleasant medical experiences. They think medical personnel will take appropriate action to deal with it.

Based on the description above, see the understanding related to medical experience, betrayal institutional, trust in the doctor, and patient trust in health care. Secondly, there is an impact of institutional betrayal of trust in-hospital treatment. Three, medical experiences affect patients' confidence in healthcare. Fourthly, doctor trust has an impact on the trust of people in health care. This study aims to examine, supported by previous studies, the effects of medical experience on institutional trashing, doctor trust, and patient trust in health care in the hospital in Jakarta, which have rarely found research related to these four variables in Jakarta.

\section{LITERATURE REVIEW}

Patient experience, according to Ralston et al. (2010), namely feedback from patients regarding "what happened "while receiving medical services with various characteristics "based on evidence." Xie et al. (2019) describe patients' direct feelings and experiences when receiving medical benefits referred to as patient experiences. Hospitals need to provide high-quality services so that patients have a pleasant experience (Ahmad, Burt, and Roland, 2014). The better the experience felt by the patient, the better the image of the hospital. Furthermore, the measurement of medical experience adopts the theory of Jenkinson, Coulter, and Bruster (2002) in Leonardsen et al. (2017) with seven dimensions (information and education; emotional comfort; respect for patient preferences; Physical comfort; family and friend participation; continuity and transition).

Institutional betrayal (P.I.) is said by Smith (2017) as a loss experienced by a person for their reliability and trust in the institution. Chrystal, Jennifer, Candice, and Emma (2017) say that institutional betrayal occurs when trust is breached lack of attention to the interests of the patient's health, and unexpected adverse outcomes for patients. The emergence of this betrayal will undoubtedly make someone leave the institution due to the loss of distrust, trauma, and disappointment. Hadiand Indradewa (2019) stated that the quality of service depends on the service received. Furthermore, the measurement of institutional betrayal adopts Smith and Freyd's (2014) theory, which is the institutional betrayal specifically experienced by someone when doing health care.

According to Dugan et al. (2005), patient trust in health services, namely the trust that is created due to the greater willingness felt by patients to seek care and comply with the 
recommended treatment recommendations. According to Smith (2017), patient trust is the patient's belief in the health services provided and does not take advantage of something that will harm the patient. Furthermore, patients' trust in health services is measured by adopting the theory of Straten, Friele, and Groenewegen (2002) in Schee, Groenewegen, and Friele (2006), which shows their level of trust in the current and future health care system with six dimensions (trust in the patient). The central focus of caregivers; trust in the professional expertise of caregivers; trust that macro-level policies will not have negative consequences for patients; trust in the quality of care; trust in communication and provision of information; trust in the quality of cooperation between caregivers).

The definition of trust in doctors based on Anderson and Dedrick (1990) is a set of expectations that patients get from their doctors. Mechanik and Meyer (2000) define trust in doctors as a set of expectations that health care providers will provide the best service for patients with good intentions and know what patients need. Likewise, Handiniand Ruswanti (2016); Kulsumand Syah (2017) explain that patients who receive services according to what is required, of course, tend to give a positive response. By believing in doctors, it is expected that it will positively impact patient health through routine treatment. Furthermore, trust in doctors is measured by adopting the theory of Kao et al. (1998) in Dugan et al. (2005), where patients who believe in doctors will feel satisfied based on the doctor's services provided during the treatment process.

Mutual understanding and trust are needed, said Shoemaker and Smith (2019), as a health service process in the hospital between the hospital administration systems to service recipients. However, patients will more easily identify the shortcomings received during health care as an unpleasant medical experience and consider it a betrayal institutional (Smith, 2017). Meanwhile, the hospital realizes that betrayal institutional occur based on accidents and cannot be avoided during the treatment process. Therefore, hospitals need to provide quality services to create a medical experience as expected and create a sense of satisfaction for patients (Muniret et al., 2019; Elizar, Indrawati, and Syah, 2020). Based on this, it can be concluded that medical experience influences betrayal institutional (Smith, 2017; Taian et al., 2017; Lewis et al., 2019; Klest et al., 2020). Based on the literature above, the following hypotheses can be proposed:

$\mathrm{H} 1$ : The more medical experience is, the lesser the institutional treason.

Social institutions, government, private sector, and other organizations, which are supposed to protect people who seek and need protection and welfare, are often abused by influential persons in these institutions. Where the abuse of authority will have a negative impact, which is referred to as a betrayal institution, Smith (2014) said that someone who experiences betrayal institutional would experience stress and harm physical health. According to Smith (2017), Shoemaker and Smith (2019), Lewis et al. (2019), betrayal institutional will not only affect the patient's view of the health services obtained but will affect the patient's trust. Therefore, patients should full health services. This research confirms prior studies' findings. This research confirms prior studies' findings, patient's true confidence be built in the hospital being visited. Based on the literature above, the following hypotheses can be proposed:

$\mathrm{H} 2$ : the higher the institutional balance, the lower the trust for the patient in health care.

During health care in a hospital, patient involvement is required, which is known as the relationship between doctor and patient. It can be said that each other must trust each other between doctors and patients (Setyawan, 2017). Trust in doctors, Smith said (2017), has an impact on patient experience. If the experience created is as expected, it undoubtedly affects patient trust. This means that if the services provided are following expectations, a pleasant experience will be created, and customers will believe that satisfaction is created (Nurlitasariand Syah, 2016; Kotler and Keller, 2016). Based on this, Brenann et al. (2013), Sieck et al. (2018), Rasiah et al. (2020) concluded that medical experience influences patients' trust in health services. Based on the literature above, the following hypotheses can be proposed:

H3: the higher the medical experiences, the higher the trust of the patient in health care. 
Safran et al. (1998) stated that a patient's trust in a doctor is recognized as the center of the relationship between doctor and patient. Trust is built when service providers are interested in fulfilling what customers need and want (Kishadaand Wahab, 2015). Trust is related to active involvement during medical care and obeying treatment recommendations given by the medical team, doctors, and nurses. Smith (2017) said that trust in doctors strongly influences patient trust in the quality of health services provided. The results of research support this by Hall et al. (2002), Dugan et al. (2005), Zhao et al. (2015) stated that trust in a doctor has an influence on patient trust in the hospital. Based on the literature above, the following hypotheses can be proposed:

$\mathrm{H} 4$ : the higher the trust in the doctor, the higher the trust for a patient in health care.

The study model is based on the description above described as follows:

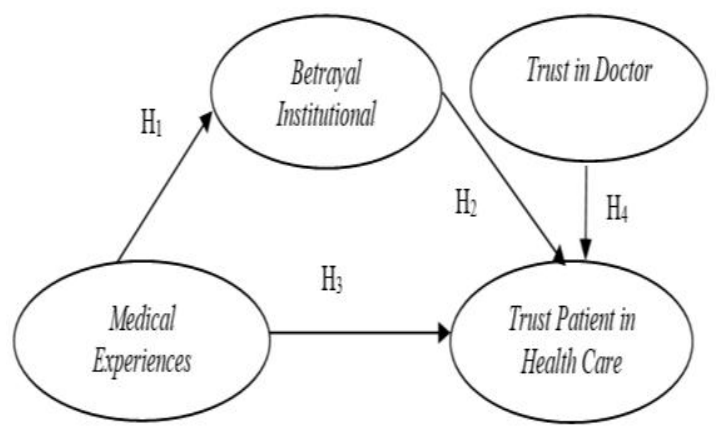

Figure 1 - Research Model

\section{METHODS OF RESEARCH}

This quantitative research is deductive, with exogenous variables (medical experiences and trust in doctors) and endogenous variables (betrayal institutional and patient trust in health care). They were collecting data using a survey method by distributing questionnaires. Measures were taken using the Likert scale and the average increased medical experience variable in Jenkinson et al. (2002) adopted by Leonardsen et al. (2017), the institutional betrayal institutional measurement variable was adopted by Smith (2017), the trust patient measurement in the health care variable from Straten et al. (2002) in Schee et al. (2006) so that the total number of questions in the study was 61 questions.

Patients at Hospital $X$ in Jakarta were focused on the study by a targeted technique of sampling in the X-Hospital region of Jakarta; patients receiving treatment more than two twice; patients aged above 17 years, June 2020 - July 2021. The initial data collection technique Is depicted by distributing an initial questionnaire (pre-test) to 30 respondents.

Methods of data analysis using SPSS and Structural Equation Modeling (SEM). Taking a large number of samples according to Hair, Anderson, Tatham, and Black (2014), at least 5-10 times the number of questionnaires, the number of questionnaires used was sixty-one with a research sample of $305(61 \times 5)$ respondents. Furthermore, confirmatory factor analysis is being utilized to test the validity by looking at the Kaiser-Meyer-Olkin sample measurement (KMO) and sample adequacy measures (MSA)) with good conditions if the value with a minimum limit of 0.5 with 1 component Matrix. The results show that all statements of medical experiences, betrayal institutional, trust in doctor and trust patient in health care are all declared valid, with KMO and MSA values> 0.5 with 1 component matrix. In the reliability test, all inconsistent statements have expressed reliability with alpha Cronbach $>0.6$ (Sekaran and Bougie, 2017).

\section{RESULTS AND DISCUSSION}

The results of data processing using SEM involving a sample of 305 outpatients at hospital $X$ in the Jakarta area, showing all valid indicators on the medical experiences 
variable with a factor loading value $(>0.50)$ and at t-value greater than t-table (1.96) at the $5 \%$ significance level. While the results show invalid on the betrayal institutional variable indicator at Bl13 (0.12) and Bl14 (0.16), the trust in doctor variable is invalid on PTD1 (0.3, 7 ), and trust patient in health care is ailing on PTHD6 (0.21). Furthermore, the construct reliability test meets the reliability requirements with all C.R. values meeting the reliable needs, namely values above 0.60 , on medical experiences (0.95), betrayal institutional $(0.95)$, trust in doctor $(0 ., 86)$, and trust patient in health care $(0.93)$. On the VE value, which is a value above 0.50 , it is reliable, on medical experiences (0.77), betrayal institutional $(0.61)$, trust in doctor $(0.5,7)$, and trust in the patient in health care (0.72) (Hair et al. 2014).

The structural model equations from this research can be seen in the $\mathrm{R}^{2}$ value, where for each equation; the function shows how far the independent variable can explain the dependent variable. The first analysis, institutional betrayal, is influenced by medical experience with an R2 of 0.28 . The second analysis, jointly betrayal institutional, medical expertise and trust in doctor affect patient confidence in health care with R2 of 0.93 .

Analysis of model suitability based on group 1 to group 7, almost all test results showed good fit on: Chi-Square, ECVI, AIC and CAIC, Fit Index. There are close fit results on RMSEA, marginal fit on Critical N, and Goodness of Fit. Thus, it is concluded that the suitability of all models has met the requirements. Furthermore, this research produces a path diagram as follows:

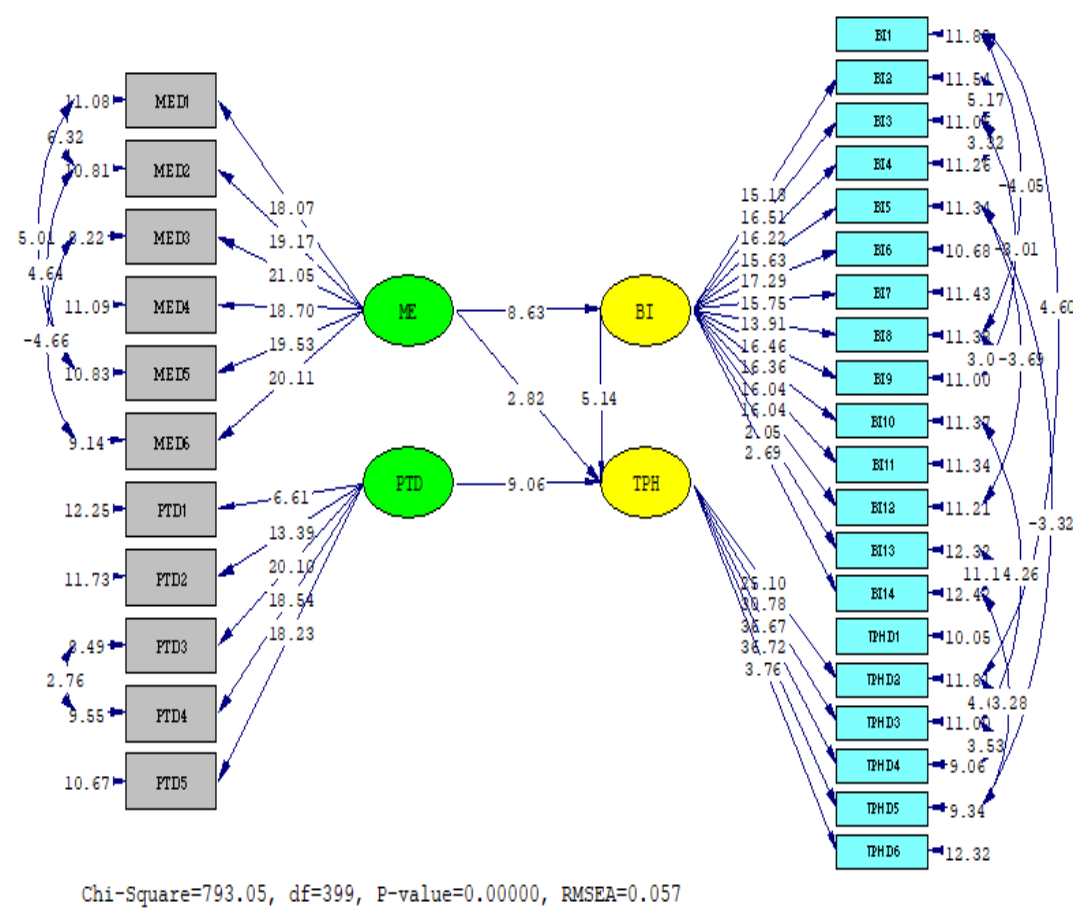

Figure 2 - Path Diagram T-Value

The findings of the first hypothesis test $(\mathrm{H} 1)$ demonstrate that medical experiences influence institutional betrayal in outpatients in hospitals in the Jakarta area. The results of this study corroborate the results of research by Tamaian et al. (2017), Lewis et al. (2019), Klestet al. (2020) that medical experiences influence institutional betrayal. The occurrence of institutional betrayal will damage the hospital's reputation and, on the other hand, also harm the patient. Therefore, a pleasant medical experience is needed. It is essential to build medical experiences that can create an enjoyable experience and foster patient confidence in minimizing institutional betrayals.

The findings of the second hypothesis testing $(\mathrm{H} 2)$ show that institutional betrayal influences patient trust in health care in outpatients in hospitals in the Jakarta area. The results of this study are in line with the results of research by Smith (2017), Shoemaker and Smith (2019), Lewis et al. (2019), namely, institutional betrayal influences trust in the patient 
in health care. The emergence of institutional betrayal will undoubtedly impact a negative assessment for patients, and this will certainly affect their trust in-hospital services that have been violated, which ultimately affects the patient's trust in health care.

Results of the second hypothesis test $(\mathrm{H} 2)$ show that medical experiences influence trust in patients in health care for outpatients in hospitals in the Jakarta area. This research strengthens the findings of other investigations, which state that medical experiences influence trust in patients in health care (Brenannet al., 2013; Sieck et al., 2018; Rasiahet al., 2020). Building patient trust is needed to maintain the good name of the hospital. Therefore, it is essential to create pleasant medical experiences. This will significantly benefit the hospital when it can build patient trust in health care because this may cause a good image of the hospital to attract other prospective patients for treatment.

The findings of the second hypothesis test $(\mathrm{H} 2)$ show that doctors' trust affects inpatient health care for outpatients in hospitals in the Jakarta area. This research enhances the results of previous studies, which stated that trust in doctors affected patient confidence in health care (Hall et al., 2002; Dugan et al., 2005; Zhao et al., 2015). Patients consider the hospital to be able to provide quality doctors so that patients believe in the doctor's services, which impacts the patient's trust in the hospital. It can be said that their hopes for doctors and hospitals have been fulfilled.

\section{CONCLUSION}

This study concludes that all the proposed hypotheses support the results of previous researchers, and there are several limitations in this study. Namely, this study only discusses the variables of medical experiences, betrayal institutional, trust patient in health care, and trust in doctor with limited samples of outpatients at a hospital in the Jakarta area. In further research, it is suggested to add other variables to measure the extent of patient confidence, expand the scope of the sampling area, and the possibility of respondents filling out a questionnaire based on the ideal conditions expected, not on actual needs.

The purpose of this study was to determine the effect of medical experience on betrayal institutional, trust in the doctor, and patient trust in health care in outpatients in hospitals in the Jakarta area. Hospital leaders can provide training and development to improve the skills and knowledge of medical workers. This is necessary to improve the performance of medical officers to build excellent and satisfying medical services to minimize the occurrence of betrayal institutional and build patient confidence in both the medical staff and the hospital. Hospital leaders need to develop moral values among medical staff wherein the work they are required to be polite, friendly, have good communication, and the need to improve the performance of the hospital system that is effective, efficient, and as promised accurately and reliably. It is hoped that professional medical personnel and work systems supported by the latest technological sophistication can minimize institutional betrayal and increase patient confidence in doctors.

\section{REFERENCES}

1. Amalia, L. (2013). Analisis Hubungan Kepuasan dengan Loyalitas Konsumen terhadap Sepeda Motor Yamaha Vixion pada Bengkel Abadi Motor Kebon Jeruk Jakarta Barat. Jurnal Ekonomika. Vol 4, No 2.

2. Amor, N. E. H. B., Talbi, D., and Almubrad, A. N. (2018). Impact of Health Service Quality on Patient Loyalty at King Khalid University Hospital in Riyadh, Saudi Arabia. Asian Journal of Economics, Business, and Accounting. 6(2), 1.

3. Anderson, L.A., and Dedrick, R.F. (1990). Development of the trust in physician scale: a measure to assess interpersonal trust in patient-physician relationships. Psychol Rep. 67:1091-1100.

4. Brennan, M. D., and Monson, V. (2014). Professionalism: good for patients and health care organizations. Mayo Clinic Proceedings. 89(5), 644. 
5. Dugan, E., Trachtenberg, F., and Hall, M.A. (2005). Development of abbreviated measures to assess patient trust in a physician, a health insurer, and the medical profession. BMC Health Services Research. 5:64.

6. Elizar, C., Indrawati, R., and Syah, T.R. (2020). Service Quality, Customer Satisfaction, Customer Trust, and Customer Loyalty in Service of Pediatric Polyclinic Polyclinic Over Private H Hospital of East Jakarta, Indonesia. Journal of Multidisciplinary Academic. Vol 4, No 2.

7. Erisha, C., Indradewa, R., Syah, T.Y.R., and Lestariani, R.I. (2021). Implementation of Medical and Non-Medica IRisk Management Infertility and Gynecology Over Kamala Clinics. Journal of multidisciplinary Academic. Vol 5, No 1.

8. Fiscella, K., Meldrum, S., Franks, P., and Shields, C.G. (2004). Patient Trust is it Related to Patient-Centered Behaviour Primary Care Physicians?. Medical Care. Vol 42, Number 11.

9. Hadi, D.R., and Indradewa, R. 2019. The Service Quality Effect on Corporate Reputation, Customers Satisfaction, and Loyalty. Journal of multidisciplinary Academic. Vol 3, No 3.

10. Hair, J.F, Black, W.C. Babin, B.J., and Anderson, R.E. (2014). Multivariate Data Analysis. Exploratory Data Analysis in Business and Economics. USA: Prentice-Hall International.

11. Hall, M.A., Zheng, B., Dugan, E., Camacho, F., Kidd, K.K., Mishra, A., Balkrhisnan, R. (2002). Measuring Patients' Trust in Their Primary Care Providers. Medical Care Research and Review. Vol. 59 No. 3.

12. Handini, S., and Ruswanti, E. (2016). The Impact of the Impulse Buying Dimension and Cherry Picking: an Empirical Study. Faculty of Economic and Business University Gadja Mada. Vol 31, No 1.

13. Henrick, S., Brennan, B., and Monturo, C. (2016). Leadership, defined: What's your style, and how's it perceived?. Nursing Management. 47(10), 30.

14. Hulu, P., and Ruswanti, E. (2018). Pengaruh Kualitas Produk, Promosi Brand Image and Kepercayaan Konsumen terhadap Intensi Pembelian (Studi Kasus pada Minumanlsotonik Pocari Sweatdi Wilayah Tangerang). IOSR Journal of Buusiness and Management.

15. Jenkinson, C., Coulter, A., Bruster, S. (2002). The picker patient experience questionnaire: development and validation using data from in-patient surveys in five countries. International Journal Qual Health Care. 4(5):353-8.

16. Kao, A. C., Green, D. C., Zaslavsky, A. M., Koplan, J. P., and Cleary, P. D. (1998). The relationship between method of physician payment and patient trust. JAMA. 280(19), 1708.

17. Kim, A.M., Bae, J., Kang, S., Kim, Y.Y., and Lee, J.S. (2018). Patient factors that affect trust in physicians: a cross-sectional study. BMC Family Practice. 19.

18. Kishada, Z.M., and Wahab, N.A. (2013). Factor Affecting Customer Loyalty in Islamic Banking: Evidence from Malaysian Banks. International Journal of Business and Social Science. Vol. 4 No. 7.

19. Klest, B., May, C., Smith, C.P., and Hosenfeld, J.M. (2020). COVID-19 Has United Patients and Providers Against Institutional. American Psychological Association. Volume $12,1$.

20. Kotler, P., andKeller, K.L. (2016).Marketing Management. 15th Edition New Jersey: Pearson Pretice Hall, Inc.

21. Kulsum, U., and Syah, T.Y.R. (2017). The Effect of Service Quality on Patient's Loyalty with Patient's Satisfaction Mediation (Studies in hospitals Balaraja). International Journal of Business and MManagementInvention.

22. Lewis, C.L., Rohling, J.L., Selwyn, C.L., Lathan, E.C. (2019). Once BITTEN, Twice Shy: An Applied Trauma-Informed Healthcare Model. Nursing Science Quarterly. Vol. 32(4) 291-298.

23. Leonardsen et al. (2017). Evaluating patient experiences in decentralized acute care using the Picker Patient Experience Questionnaire; methodological and clinical findings. BMC Health Services Research. 17:685. 
24. Munir, M., Syah, T.Y.R., Pusaka, S., and Kusumapradja, K. Unggul Daycare Human Resource Business Planning. (2019). Journal of multidisciplinary Academic. Vol 3, No 4.

25. Neliwati. (2018). Metodologi Penelitian Kuantitatif (Kajian Teori and Praktik). Medan: CV.Widya Puspita.

26. Nurlitasari, L., and Syah, T.Y.R. (2016). Pengaruh Kualitas Layanan terhadap Kepuasan and Loyalitas (Kasus: Rumah Sakit Mediaka Permata Hiajau Jakarta Barat). Media Studi Ekonomi. Jilid 9.

27. Ralston, J., Coleman, K., Reid, R. Handley, M.R., and Larson, E.B. (2010). Patient experience should be part of meaningful-use criteria. Health Aff. 29(4):607-613.

28. Rasiah, S., Jaafar, S., Yusof, S., Ponnuduroi, G., Chung, K.P.Y., and Amirthalingam, S.D. (2020). A study ofthe nature and level of trust between patients and healthcare providers, its dimensions and determinants: a scoping review protocol. BMJ Open.

29. Safran, D. G., Kosinski, M., Tarlov, A. R., Rogers, W. H., Taira, D. A., Lieberman, N., and Ware, J. E. (1998). The Primary Care Assessment Survey: tests of data quality and measurement performance. Medical care. 728.

30. Sarker, A.S., and Uddin, N.R.M.B. (2013). Influence of Service Quality on Customer Satisfaction in Retail Banking: A Study on Some Private Commercial Banks in Bangladesh. Green University Review. Vol 4.

31. Schee, E.V., Groenewegen, P., and Frielea, R. (2006). Public trust in health care: a performance indicator. J Health Organ Manag. 20:468-476.

32. Sekaran, U., and Bougie, R. (2017). Metode Penelitian untuk Bisnis Pendekatan. Pengembangan-Keahlian. Jakarta: Salemba Empat.

33. Setyawan, F.E.B. (2017). Medical Communication: Doctor-Patient Relations. Jurnal Unimus. Vol 1, No 4.

34. Sieck, C. J., Hefner, J. L., and McAlearney, A.S. (2018). Improving the patient experience through patient portals: Insights from experienced portal users. Patient Experience Journal. Vol. 5, Iss. 3.

35. Shoemaker, K., and Smith, C.P. (2019). The impact of patient-physician alliance on trust following an adverse event. Patient Education Counseling. 102. 1342-1349.

36. Smith, C. P. (2017). First, not harm: institutional betrayal and trust in health care organizations. Journal of multidisciplinary healthcare. 10, 133.

37. Smith, C. P., and Freyd, J. J. (2014). Institutional betrayal. American Psychologist. 69(6), 575.

38. Straten, G.F., Friele, R.D., Groenewegen, P.P. (2002). Public trust in Dutch health care. Soc Sci Med. 55:227-234.

39. Tamaian, A., Klest, B., and Mutschler, C. (2017). Patient dissatisfaction and institutional betrayal in the Canadian medical system: A qualitative study. Journal of Trauma and Dissociation. 18(1), 38.

40. Xie et al. (2019). What Are the Risk Factors of Negative Patient Experience? A CrossSectional Study in Chinese Public Hospitals. The Journal of Health Care Organization, Provision, and Financing. Vol 56: 1-7

41. Zhao, D.H., Rao, K.Q., and Zhang, Z.R. (2015). Patient Trust in Physicians: Empirical Evidence from Shanghai, China. Chinese Medical Journal.129:814-8. 